\title{
O III CONGRESSO DA GEOGRAFIA PORTUGUESA
}

\author{
SÉRGIO CLAUDINO ${ }^{1}$
}

Organizado pela Associação Portuguesa de Geógrafos e pelo Instituto de Geografia da Faculdade de Letras da Universidade do Porto, de 25 a 27 de Setembro de 1997 decorreu no Porto o III Congresso da Geografia Portuguesa, subordinado ao tema A interdisciplinaridade na Geografia Portuguesa: novos e velhos desafios.

Pretendeu-se, pois, estimular a reflexão em torno de uma perspectiva relativamente consensual entre os geógrafos - a da Geografia como ciência interdisciplinar e integradora, como referem os promotores do Congresso -, mas que tem merecido daqueles um reduzido debate, apesar das exigências de produção científica apontarem para uma crescente interpenetração de saberes.

Na conferência inicial, intitulada Nós e os Outros, o Professor Jorge Gaspar fez uma abordagem crítica da preservação das paisagens rurais e urbanas no nosso país e reflectiu sobre quer as atitudes dos geógrafos em relação à sua própria ciência, quer o diálogo e posicionamento da Geografia perante outras áreas científicas e tecnológicas.

As comunicações foram organizadas em torno de quatro temáticas, as duas primeiras mais directamente relacionadas com o tema do Congresso:

\section{NOVAS PONTES DE RELACIONAMENTO ENTRE O NATURAL E O SOCIAL}

Em duas sessões, foram apresentadas 10 comunicações, 4 das quais sobre a geomorfologia e o povoamento do litoral. As restantes debruçaram-se sobre a flora dos espaços verdes, a diversidade biofísica do território, as paisagens de áreas de montanha, turismo em áreas protegidas e Geografia dos desportos radicais.

\section{GEOGRAFIA E INTERDISCIPLINARIDADE NO INTERIOR DAS CIÊNCIAS SOCIAIS}

Também em duas sessões, foram apresentadas 16 comunicações subordinadas a temas muito diversos, da globalização à teledetecção, passando pelas orientações

\footnotetext{
${ }^{1}$ Assistente da Faculdade de Letras, Universidade de Lisboa. Investigador do Centro de Estudos Geográficos da Universidade de Lisboa. Centro de Estudos Geográficos, Faculdade de Letras, Cidade Universitária 1699 LISBOA CODEX; tel: (351-1) 79651 62; fax: (351-1) 79600 63; email: sclaudino@fc.ul.pt
} 
recentes da Geografia Social, o aproveitamento de recursos energéticos e minerais ou a gestão de resíduos urbanos e industriais.

\section{A GEOGRAFIA APLICADA NO PLANEAMENTO E NO ORDENAMENTO REGIONAL E LOCAL}

Com seis sessões, por vezes funcionando em simultâneo, esta foi a temática com maior número de comunicações - 40. A Geografia Urbana mereceu uma atenção privilegiada; o planeamento, os serviços, a demografia ou o poder local, entre muitos outros assuntos, foram igualmente objecto de comunicações.

\section{PAPEL DA GEOGRAFIA NO SISTEMA EDUCATIVO}

Numa única sessão com 9 comunicações, destacaram-se os relatos de experiências lectivas inovadoras desenvolvidas no ensino básico e secundário, centrando-se as restantes intervenções principalmente no papel formativo da disciplina de Geografia.

$\mathrm{Na}$ tarde do dia 26 de Setembro foram apresentados vários painéis de Geografia Física, na sua maioria relativos à geomorfologia litoral, a confirmar a tendência já identificada na apresentação de comunicações. Em simultâneo realizou-se uma mesa redonda sobre Geografia nos países lusófonos, coordenada pelo presidente da Sociedade de Geografia de Lisboa (a confirmar a actual aproximação entre esta instituição e os geógrafos portugueses) e com representantes do Brasil, Moçambique e Cabo Verde. Nesta mesa redonda foram descritas as distintas situações da Geografia naqueles três países e manifestada a intenção de intensificar a cooperação entre as comunidades de geógrafos.

Ao fim da tarde, a Ministra do Ambiente reflectiu sobre Política e Educação Ambiental, numa conferência marcada pelas referências afectivas por parte deste membro do governo, oriundo do Porto.

Paralelamente à organização do Congresso, realizou-se, na noite do dia 26 , uma interessante visita à cidade, que explorou aspectos da sua vida nocturna.

No dia 27 de Setembro, realizaram-se 3 das 7 visitas de estudo inicialmente programadas: Alto Douro, Parque da Peneda-Gerês/Xurés e Trás-os Montes: Paisagem-Fronteira-História que decorreram da melhor forma e registaram o agrado generalizado dos participantes.

O cancelamento de visitas de estudo decorrerá da diminuição de participantes no Congresso, comparativamente ao realizado em 1994. Registaram-se 340 inscrições, das quais 140 de docentes do ensino básico e secundário, apenas mais três do que de docentes e investigadores do ensino superior; 50 participantes exercem outras actividades e ignora-se a origem profissional de 13 inscritos. A aproximação do número de participantes dos dois primeiros grupos decorre da menor participação de professores do ensino básico e secundário, mas reflectirá igualmente o aumento do número de geógrafos no ensino superior. Este, aliado ao maior número 
de profissionais de outras proveniências, constitui um sinal claro da diversificação das actividades profissionais da nossa comunidade científica.

De referir, ainda, a participação activa de cinco geógrafos brasileiros nos trabalhos do Congresso.

Como decorre da distribuição das comunicações, foram poucos os que se propuseram reflectir sobre os desafios que a interdisciplinaridade coloca à Geografia Portuguesa. Este terá sido um dos aspectos menos conseguidos, que traduz a própria debilidade do debate epistemológico entre nós. Ao contrário, cumpriu-se uma das principais finalidades deste tipo de reuniões: o aparecimento de jovens geógrafos que apresentaram estudos de assinalável qualidade, em áreas que merecem habitualmente pouca atenção.

Foi evidente a disparidade entre o número de comunicações de Geografia Humana e de Geografia Física. Pelos títulos, apenas duas intervenções se referiam à Europa ou a países europeus, o que sugere que, onze anos passados sobre a integração portuguesa na União Europeia, a Geografia portuguesa continua pouco desperta para as questões comunitárias. Por outro lado, e dando continuidade às próprias intenções formuladas neste Congresso, aguarda-se que surjam futuramente comunicações que contemplem os vários países lusófonos.

A escassez de intervenções sobre algumas das temáticas propostas e a diversidade de assuntos nelas abordadas ajudarão a explicar, mas só em parte, a dificuldade dos organizadores em as agrupar em sessões com alguma coerência temática. A própria listagem das comunicações, por sessão, de acordo com a ordem alfabética dos seus autores, acabou por ser geralmente adoptada para definir a sequência com que foram apresentadas, o que agravou a falta de ligação entre comunicações que se sucediam. Como é infelizmente habitual neste tipo de reuniões, a preocupação em fazer cumprir os horários das sessões limitou o debate sobre as comunicações apresentadas.

O Congresso permitiu a muitos dos participantes conhecer as novas instalações da Faculdade de Letras da Universidade do Porto. A própria necessidade de realizar a sessão inaugural nas instalações da Reitoria reflectiu algumas das dificuldades notadas num edifício sem grandes espaços de encontro. Pela concorrência deste e de outros aspectos, sentiu-se a falta de momentos fortes, formais e informais, que aproximassem os participantes.

Este Congresso constituiu, em qualquer caso, um acontecimento muito positivo e marcante para a Geografia portuguesa.

O III Congresso, bem como os que o precederam, lembra de novo a necessidade de repensar o funcionamento destas reuniões, no sentido de valorizar o espaço de intervenção dos que a elas acorrem, de forma a que os inscritos possam ser cada vez mais congressistas. 